\title{
Exploring the Three Phases of Motivation in The Learning of Japanese as A Foreign Language
}

Choong Pow Yean, Nur Anisah Tan Abdullah, Normah Ahmad, Noor Hanim Rahmat, Nor Rasimah Abdul Rashid, Sarinah Sharif

To Link this Article: http://dx.doi.org/10.6007/IJARBSS/v12-i1/12109

DOI:10.6007/IJARBSS/v12-i1/12109

Received: 06 November 2021, Revised: 09 December 2021, Accepted: 27 December 2021

Published Online: 22 January 2022

In-Text Citation: (Yean et al., 2022)

To Cite this Article: Yean, C. P., Abdullah, N. A. T., Ahmad, N., Rahmat, N. H., Rashid, N. R. A., \& Sharif, S. (2022). Exploring the Three Phases of Motivation in The Learning of Japanese as A Foreign Language. International Journal of Academic Research in Business and Social Sciences, 12(1), 1563-1583.

Copyright: (C) 2022 The Author(s)

Published by Human Resource Management Academic Research Society (www.hrmars.com)

This article is published under the Creative Commons Attribution (CC BY 4.0) license. Anyone may reproduce, distribute, translate and create derivative works of this article (for both commercial and non0-commercial purposes), subject to full attribution to the original publication and authors. The full terms of this license may be seen

at: http://creativecommons.org/licences/by/4.0/legalcode

Vol. 12, No. 1, 2022, Pg. 1563 - 1583

Full Terms \& Conditions of access and use can be found at http://hrmars.com/index.php/pages/detail/publication-ethics 


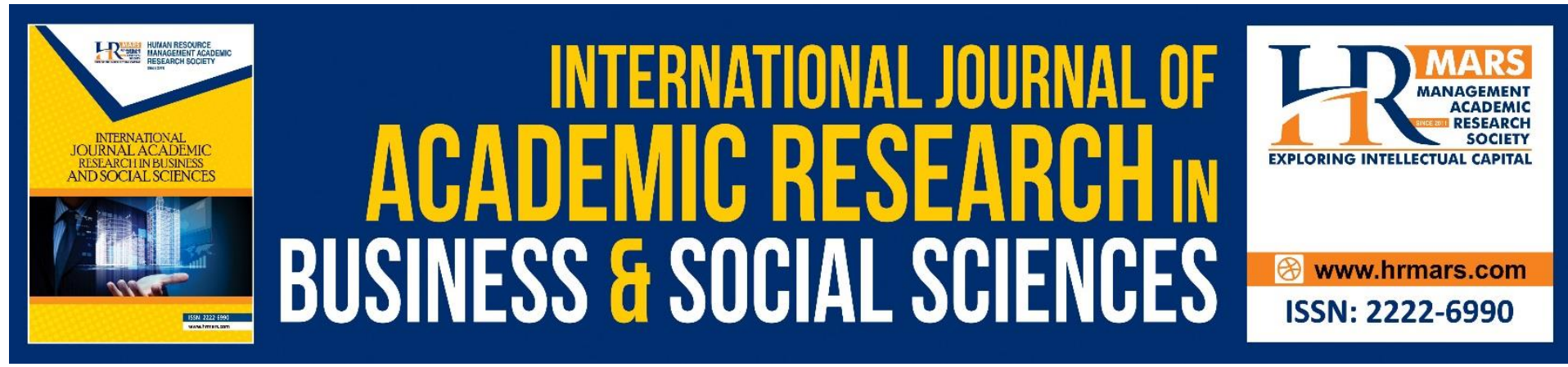

\title{
Exploring the Three Phases of Motivation in The Learning of Japanese as A Foreign Language
}

\author{
Choong Pow Yean ${ }^{1}$, Nur Anisah Tan Abdullah², Normah \\ Ahmad $^{3}$, Noor Hanim Rahmat ${ }^{4}$, Nor Rasimah Abdul Rashid ${ }^{5}$, \\ Sarinah Sharif6 \\ 1,2,3,5\&6Akademi Pengajian Bahasa, Universiti Teknologi MARA Shah Alam, ${ }^{4}$ Akademi \\ Pengajian Bahasa Universiti Teknologi MARA Cawangan Johor Kampus Pasir Gudang \\ Email: choon322@uitm.edu.my ${ }^{1}$, anistan@uitm.edu.my², normah698@uitm.edu.my ${ }^{3}$, \\ nor_rasimah@uitm.edu.my $y^{5}$,sarinah@uitm.edu.my ${ }^{6}$, \\ noorh763@uitm.edu.my
}

\section{Abstract}

Motivation is one of the prerequisites in Japanese learning. A student who excels, but does not have enough motivation, will definitely not achieve the results as expected. This study is conducted to explore the three phases of motivation in the learning of Japanese language as a foreign language using the Model of Second Language Motivations (Dörnyei \& Ottó, 1998). A quantitative survey consisting of 4 sections with items on the demographic profile and 39 items via Google Form using 5-Likert scales were used as the instruments. Questionnaires were answered by 255 students from three clusters; namely the clusters of Science and Technology, Arts and Humanities, and Business and Administration in a public university in Malaysia. Findings revealed that learners have the highest motivation during the actional stage as curiosity-driven has intrinsically motivated them to learn. Learners' initial motivation has reversed when they reached the actional stage due to their stress about the tests or examinations. However, learners' motivation bounce back during the post-actional stage and they are confident they will perform an excellent job on their assessments or assignments. This study reveals that instructors have a role to play to keep students motivated throughout the process of Japanese language learning. Further research can be done on preactional, actional and post actional stages by looking at the influence of external motivation by associating it with cognitive, affective, situational or circumstantial factors that will support and complement this study.

Keywords: Learning Motivation, Learning Japanese Language, Preactional, Actional, Post Actional

\section{Introduction}

Background of Study

As the world becomes increasingly globalised, the advantages of learning foreign languages are growing along with it, making it so that bilingualism is an important and valuable skill to possess. In Malaysia, Japanese is one of the favorite languages as a foreign 
language to learn. According to the report by the Japan Foundation (The Japan Foundation, 2015), there are 176 institutions in Malaysia offering Japanese language courses to 33,224 students, while in 2018, the number of institutions offering Japanese language has increased to 212 as well as the number of students who are learning the Japanese language has increased to 39,247 (The Japan Foundation, 2018). In Malaysia, integrative motivation is high, as well as instrumental motivation (Singh, 2021). Nevertheless, motivation is not static but dynamically developing and changing in time (Dörnyei and Ottó, 1998). Hence, it is necessary to have a greater understanding through exploring the motivation of Malaysian students on learning Japanese as a foreign language in the different stages along their study process.

In recent years, online foreign language learning has become common especially after the covid 19 pandemic since 2020. From the physical classroom, students have to adapt to learning foreign languages in cyberspaces. Some students have negative perceptions towards online teaching which they believe has a negative impact on their motivation because of lack of social interaction, a mismatch between expectations and content, organizational problems and the organization of the learning environment (Mese, 2021). However, according to Rahmat (2021), a positive stimulus that provides a positive response, modeling instructors, and also environments with supportive peers are all elements that can help learners in their online Japanese studies.

For decades, 'motivation' has attracted researchers' attention to investigate what encourages learners to continue learning. There are motivation models used by researchers to ascertain the motivation of language learning. Dornyei (1998) found that existing motivation models are insufficient in 3 scopes: (1) not sufficiently comprehensive and detailed summary of all the relative motivational influences on classroom behavior; (2) neglecting or disregarding the importance of motivational sources of executing goal-directed behavior; and (3) no justice was made to the fact that motivation is not static (Dornyei,1998). Dornyei found that motivation dynamically evolves and changes in time (1998).

The purpose of this study is to determine how students are motivated to learn a foreign language in a public university in Malaysia

\section{Statement of Problem}

Motivation

Remírez (2014) stated that areas in the economy, trade, immigration, and communication, and others make acquiring a foreign language an added value to contact and communicate with people worldwide who have used a different language and lived in a different culture. In their research, Awang Boon et al. (2021) said globalization had increased the importance of learning a foreign language in education. It has been the motivation for learners in higher education as it may be their ticket to be employed after graduation. In another research done by Amjoshoa \& Sadighi (2015), most educators and researchers accepted motivation as one of the main factors influencing foreign language learning success.

\section{Demotivation}

According to Rahmat (2020), anxiety may demotivate learners in the performance and achievements of their language studies. In similar research by Chong et al. (2019), teachers and learners are demotivating factors in foreign language learning. Learners' demotivation 
can be due to inappropriate teaching influences, styles, attitudes, and poor teaching quality by the teachers. Learners' low self-esteem and low self-worth are discouraged in their language learning process. Jahedizadeh et al. (2016) stated that learners' burnout, lack of interest, and their experiences in failing are a few factors that demotivated them from succeeding in their foreign language learning.

Hence, this study is done to investigate the three phases of motivation in the learning of a foreign language. Specifically, this investigation is done to answer the following questions;

- How is Preactional stage done in foreign language learning?

- How is Actional stage done in foreign language learning?

- How is Post actional stage done in foreign language learning?

\section{Literature Review}

What Motivates people to learn Japanese

The Japanese language is one of the most popular foreign languages in the world. According to a report by the Japan Foundation in 2019, there are 3,851,774 learners of the Japanese language outside Japan. The number of learners has increased by 30.3 times during the past 39 years. This shows that the Japanese language has a significant position in terms of popularity as a foreign language. According to Makhtiar Singh (2021), mastering a foreign language will provide graduates with an advantage in an increasingly global and diversified workplace, where a worker fluent in multiple languages will have more chances.

Nowadays, people choose to learn a foreign language for various reasons. It is critical for educators and learners to have a clear understanding of the motivational factors attributed to the desire to study a foreign language. Gardner (1972) proposed two terms that are commonly used in the field of motivation: integrative orientation and instrumental orientation. Integrative orientation refers to the positive propensity of an individual to learn a language, its culture, and its community. Instrumental orientation, on the other hand, refers to a person's practical motives for learning a language. Some people may be motivated to study a second language because it is a requirement of their studies, or because they want to find a job. Makhtiar Singh (2021) conducted a study on motivational orientations among Japanese language learners in a public university in Malaysia. The results indicated that the overall level of motivation among the Japanese language learners was high. In the integrative motivation section, it showed that the learners were strongly motivated to learn about Japanese culture and society, and they enjoyed Japanese manga, songs, movies, and TV drama series. Their interest in Japanese culture motivates them to learn the Japanese language and vice versa.

\section{How is Japanese learnt?}

Bidin (2019) carried out research focusing on attitudes, motivation, and gender affecting Japanese language learning. The finding stated the factors of attitude have helped the students learn Japanese effectively. According to the respondents, completing all the assignments given has helped them in mastering the learning of the Japanese language more quickly and effectively. Meanwhile, the research by Hoi (2021) on utilizing Japanese movies to learn the Japanese language showed watching movies helps intermediate Japanese 
learners expand their vocabulary, and improve pronunciation and listening skills. Apart from that, watching movies also promotes knowledge about culture and communication.

Motivation for Learning Languages

Dörnyei and Ottó (1998) propose a (figure 1) model of motivational evolution that distinguishes three stages. The first stage is (a) the preactional stage, where motivation to accomplish a goal is generated. Next, (b) the actional stage, is the stage during which the initial motivation has to be maintained and protected and involves executive motivation. The last stage is (c) the postactional stage, which entails some kind of evaluation of the learning process and can be referred to as motivational retrospection.

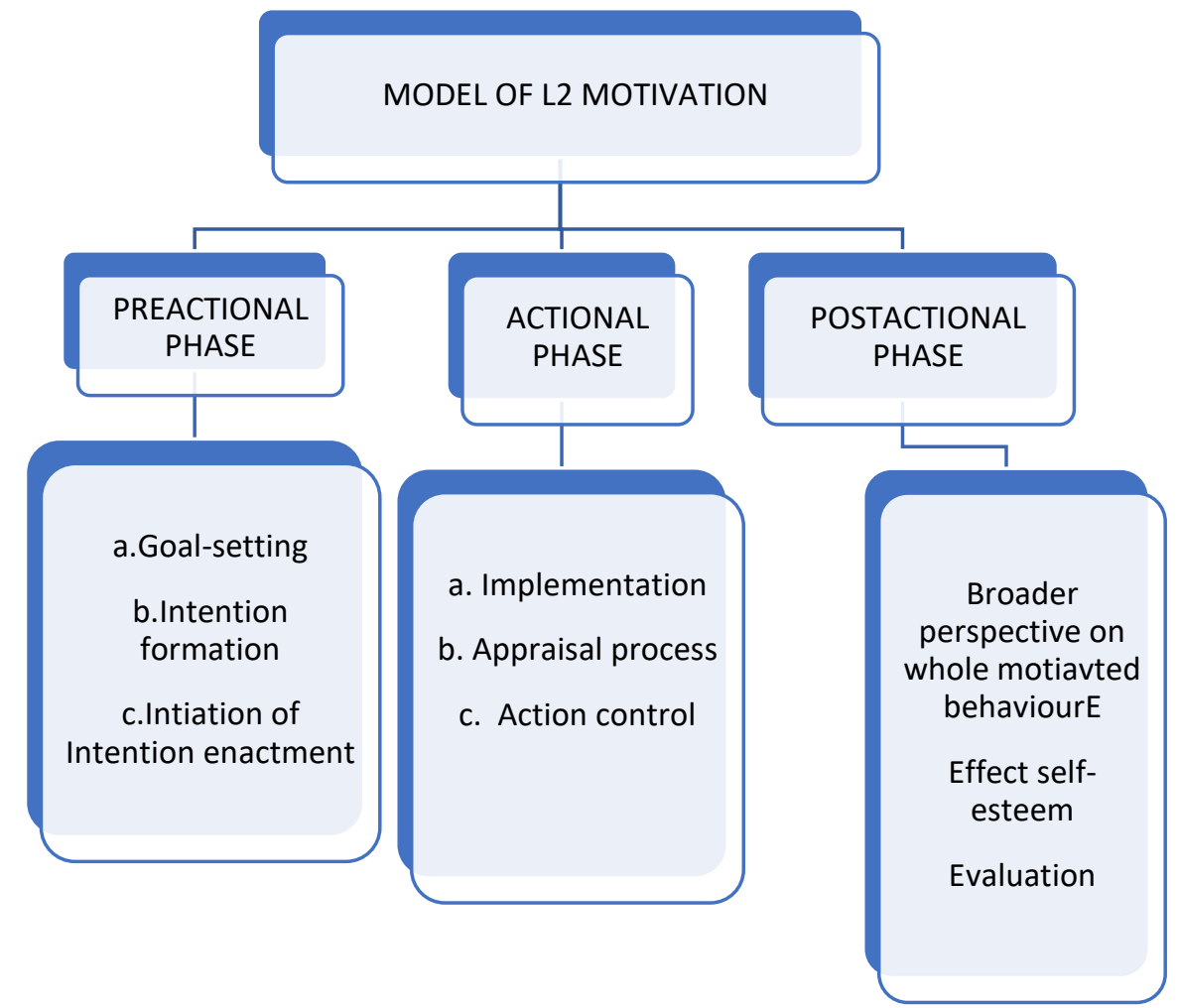

Figure 1-Model of Second Language Motivations (Source: Dörnyei \& Ottó, 1998).

\section{Past Studies}

Past Studies on Motivation to Learn Japanese

The most significant aspect of learning a foreign language is motivation. Researchers have been conducting studies related to motivation for learning a foreign language. De BurghHirabe (2019) conducted research on Japanese motivations and learning experiences as a foreign language (JFL) on learners in New Zealand. The study combines quantitative and qualitative methodologies, using open-ended questionnaires (qualitative) and an L2 motivation survey (quantitative). The data demonstrated that while integrativeness was the primary reason students chose to study Japanese at first, as they engaged in JFL learning and with the $L 2$ community, they built ideal $L 2$ selves. Positive $L 2$ learning experiences, frequently associated with an intrinsic learning orientation, sustained their JFL learning.

Rethinasamy (2021) researched to investigate the views and motivations of Malaysian students studying Japanese as a foreign language. The tool used for this research was a 
questionnaire. The research included 150 undergraduates from a Malaysian institution learning Japanese as a third language. According to the statistics, most students feel that listening, and speaking abilities are more difficult to develop than reading and writing skills. Similarly, most students are unsure about their abilities to communicate in Japanese. There is a combination of integrative and motivational factors in terms of motivation for learning Japanese.

Past Studies on Difficulties to learn Japanese

Many studies have been done to investigate the learning of Japanese language. Over the past few years, researchers have explained most of the failures to learn Japanese are influenced by several effective variables such as a lack of motivation (Osumi, A. 2019), high level of anxiety (Djafri \& Wimbarti, 2018), and more recently, learning style differences and inefficient learning strategies.

Rethinasamy (2021) have investigated Malaysian undergraduates' beliefs and motivation for learning Japanese as a foreign language in one of the universities in Malaysia. 150 undergraduates as the respondents have participated in the survey using questionnaires. The findings show that most of the students believe that listening and speaking skills are more difficult to obtain compared to reading and writing skills. Findings also indicated that most of the students lack the confidence to speak in Japanese.

Mardani (2019) conducted a study to describe the implementation of the 2013 curriculum in learning Japanese in elementary schools in Bali. From the respondents (students), it was found that the difficulty in learning Japanese characters is one of the reasons why the respondents were not interested in learning Japanese. In addition to that, Kuraesin (2021) determined the internal and external factors that have caused student learning difficulties in learning Japanese subjects for 31 students consisting of 19 female students and 12 male students. The data was collected from respondents using questionnaires. The results showed that students faced two categories of difficulties when learning the Japanese language. There were internal factors that included students' own issues and external factors which focused on the lack of encouragement from their parents to study.

\section{Conceptual Framework}

This study is rooted from motivation phases by Dörnyei \& Ottó (1998) and language skills by Setiyadi (2016). This current study is focussed only on the learning of foreign languages; specifically, Japanese. With reference to figure 2 , the motivation to learn a foreign language begins with the pre-actional stage. At this stage the learner perceives their motivation to learn as intrinsic, extrinsic and these are influenced by their task values belief. The next stage is actional stage. This stage is influenced by the learners' affective components. The learners then perform their ability to use the language via speaking and listening skills. The last stage is post-actional stage where the learners go through the post-actional stage. This is influenced by the learners' perception of self-efficacy and also their control beliefs. 


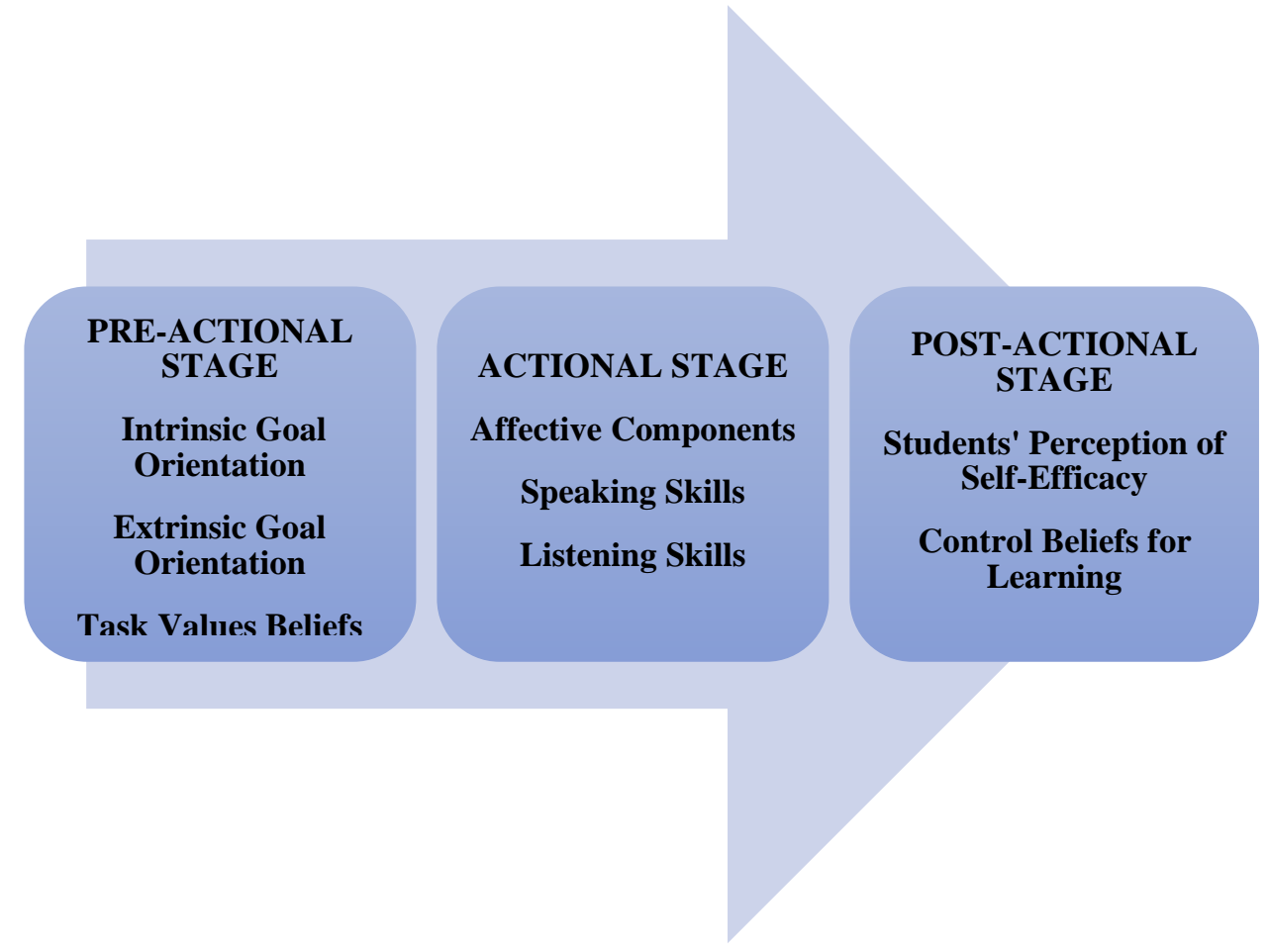

Figure 2- Conceptual Framework of the Study

Exploring the Three Phases of Knowledge in the Learning of a Foreign Language (Source: Dörnyei \& Ottó, 1998 \& Setiyadi, 2016)

\section{Methodology}

This quantitative research is done to explore the three phases in knowledge in the learning of a foreign language.

The instrument used is a survey adapted from Setiyadi (2016) and Dörnyei \& Ottó (1998). 255 respondents were purposively chosen to answer the survey. The survey has 4 main sections. With reference to Table 1 , section $A$ has items on the demographic profile. Section B has 12 items on Pre-Actional Stage, Section C has 20 items on Actional Stage, and Section D has 7 items on Post Actional Stage. 
INTERNATIONAL JOURNAL OF ACADEMIC RESEARCH IN BUSINESS AND SOCIAL SCIENCES

Vol. 12, No. 1, 2022, E-ISSN: 2222-6990 @ 2022 HRMARS

Table 1: Distribution of Items in the Survey

\begin{tabular}{|c|c|c|c|c|c|c|c|c|}
\hline $\begin{array}{l}\text { Sectio } \\
n\end{array}$ & STAGE & COMPONENTS & & $\begin{array}{l}\text { SUB- } \\
\text { COMPONENT }\end{array}$ & $\begin{array}{l}\text { No } \\
\text { Of } \\
\text { Item } \\
\text { s }\end{array}$ & $\begin{array}{l}\text { Tota } \\
\text { I } \\
\text { Item } \\
\text { s }\end{array}$ & $\begin{array}{l}\text { No } \\
\text { Of } \\
\text { Item } \\
\text { s }\end{array}$ & $\begin{array}{l}\text { Tota } \\
\text { I } \\
\text { Item } \\
\text { s }\end{array}$ \\
\hline \multirow[t]{4}{*}{ B } & $\begin{array}{l}\text { PREACTIONAL } \\
\text { STAGE }\end{array}$ & $\begin{array}{l}\text { VALUE } \\
\text { COMPONENTS }\end{array}$ & (a) & $\begin{array}{l}\text { Intrinsic Goal } \\
\text { Orientation }\end{array}$ & 4 & 12 & 4 & 12 \\
\hline & & & (b) & $\begin{array}{l}\text { Extrinsic Goal } \\
\text { Orientation }\end{array}$ & 3 & & 3 & \\
\hline & & & (c) & $\begin{array}{ll}\text { Task } & \text { Value } \\
\text { Beliefs } & \end{array}$ & 5 & & 5 & \\
\hline & & $\begin{array}{l}\text { VALUE } \\
\text { COMPONENTS }\end{array}$ & & & & & & \\
\hline \multirow[t]{3}{*}{ C } & $\begin{array}{l}\text { ACTIONAL } \\
\text { STAGE }\end{array}$ & $\begin{array}{l}\text { AFFECTIVE } \\
\text { COMPONENTS }\end{array}$ & & & & & 5 & 5 \\
\hline & & Speaking & & & & & 10 & 20 \\
\hline & & Listening & & & & & 10 & \\
\hline \multirow[t]{3}{*}{$\mathrm{D}$} & $\begin{array}{l}\text { POST ACTIONAL } \\
\text { STAGE }\end{array}$ & & (a) & $\begin{array}{l}\text { Students' } \\
\text { Perception of } \\
\text { Self- Efficacy }\end{array}$ & 5 & & 5 & 7 \\
\hline & & & (b) & $\begin{array}{l}\text { Control Beliefs } \\
\text { for Learning }\end{array}$ & 2 & & 2 & \\
\hline & & & & & & & & 44 \\
\hline
\end{tabular}

Table 2 presents the reliability statistics for the instrument. SPSS analysis revealed a Cronbach alpha of .931 thus showing high internal reliability of the instrument used. Data is collected online via google Forms. Data is then analysed using SPSS version 26. Analysed data is presented in the form of percentages and mean scores to answer the 3 research questions.

Table 2: Reliability Statistics for the Instrument

\section{Reliability Statistics}

\begin{tabular}{r|r}
$\begin{array}{c}\text { Cronbach's } \\
\text { Alpha }\end{array}$ & N of Items \\
\hline .931 & 44 \\
\hline
\end{tabular}




\section{Findings}

Findings for Demographic Profile

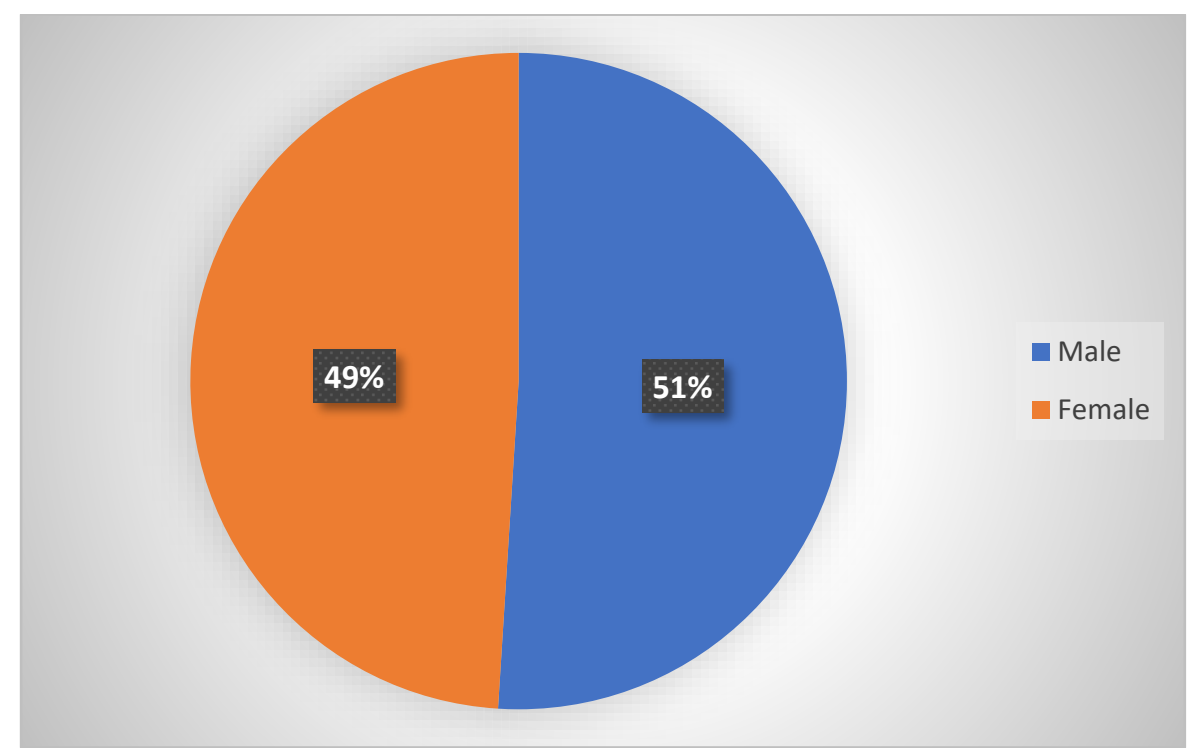

Figure 3- Pie Chart for Gender

Figure 3 shows the percentage for gender. It indicates that slightly more males participated in the survey than females.

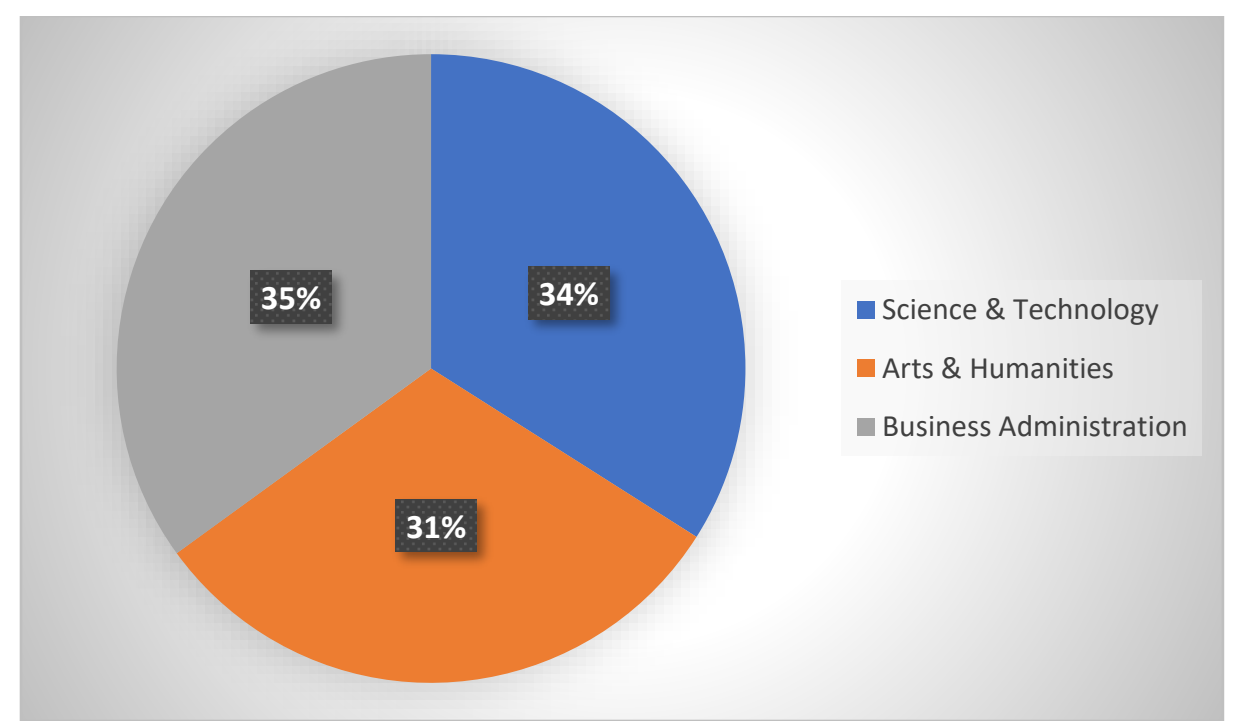

Figure 4- Pie Chart for Discipline

Figure 4 shows the percentage for discipline of respondents. It reveals that respondents who participated in this research were from three (3) disciplines. Most of them were from Business Administration, followed by Science \& Technology and Arts \& Humanities.

\section{Findings for PreActional Stage}

This section presents data to answer the research question-How is the preactional stage done in foreign language learning? The influence at the preactional stage is presented in the form of (a) intrinsic goal orientation, (b) extrinsic goal orientation and also (c) task value beliefs. 
(a) Intrinsic Goal Orientation

Dornyei (1994) distinguishes between intrinsically motivated and extrinsically motivated behaviours in language learning. According to him, intrinsically driven behaviours are those that have internal rewards, such as the pleasure of engaging in a particular activity, whereas extrinsically motivated behaviours are those that an individual engages in order to get an external reward, such as good grades.

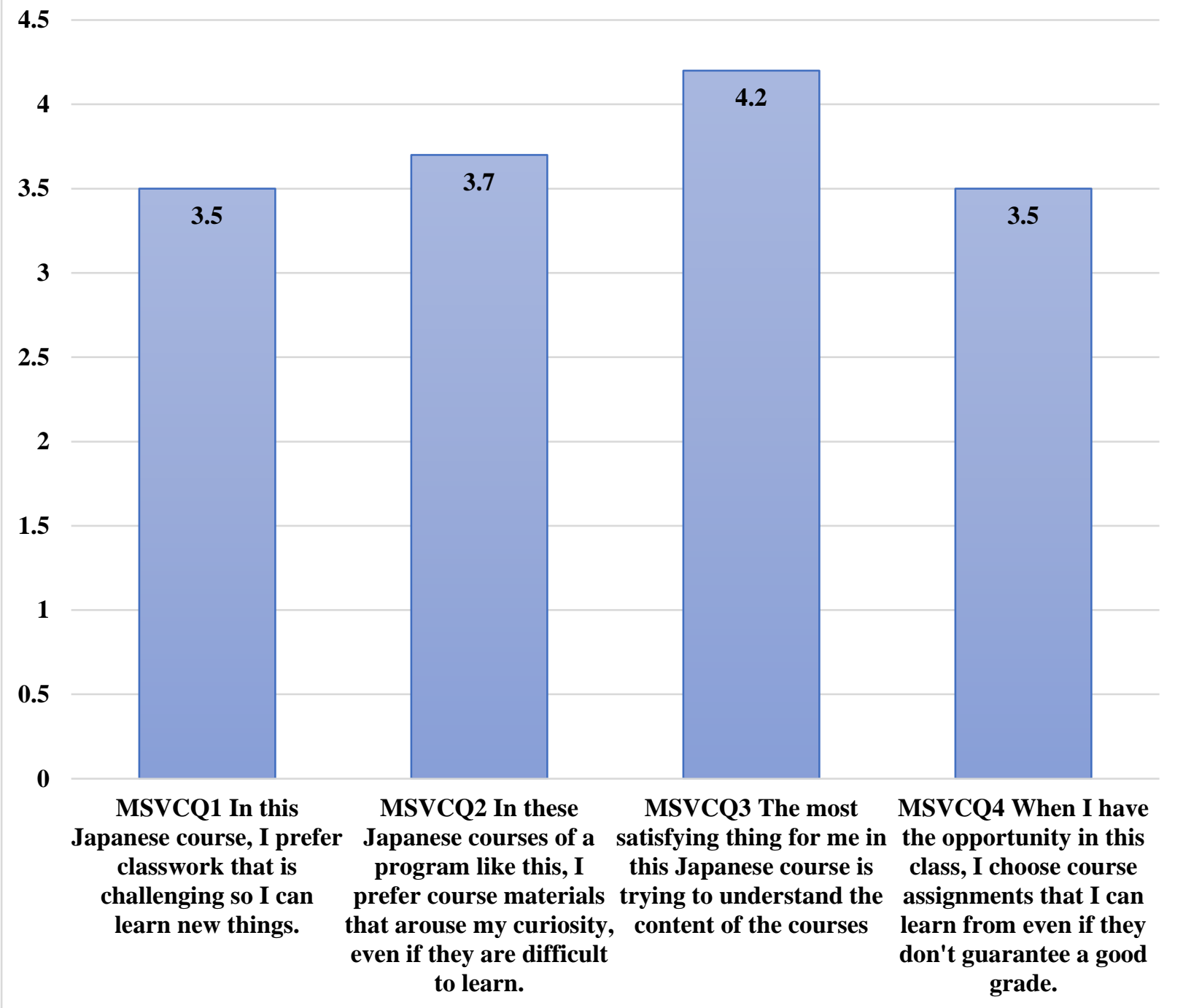

Figure 5- Mean for Intrinsic Goal Orientation

Figure 5 shows the mean score for intrinsic goal orientation. The highest mean score (4.2) is for "The most satisfying thing for me in this Japanese course is trying to understand the content of the courses", followed by "In this Japanese course of a program like this, I prefer course materials that arouse my curiosity, even if they are difficult to learn" (3.7). The lowest score (3.5) is for "In this Japanese course, I prefer classwork that is challenging so I can learn new things," and "When I have the opportunity in this class, I choose course assignments that I can learn from even if they don't guarantee a good grade." 


\section{(b) Extrinsic Goal Orientation}

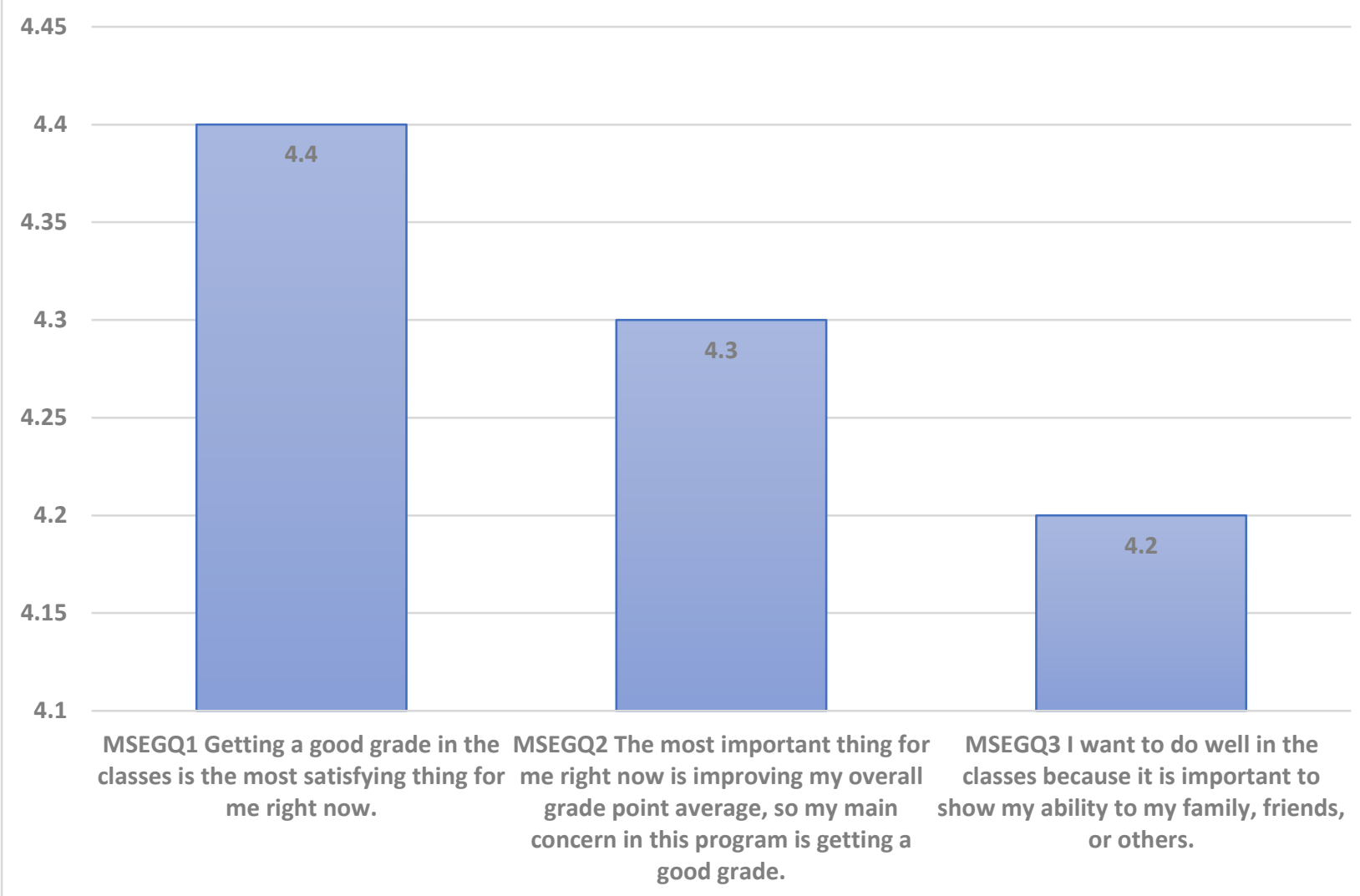

Figure 6- mean for Extrinsic Goal orientation

Figure 6 demonstrates the mean score for extrinsic goal orientation. All three items show high mean scores, with the highest one is "Getting a good grade in the classes is the most satisfying thing for me" (4.4), followed by "The most important thing for me right now is improving my overall grade point average" (4.3), and "I want to do well in the classes because it is important to show my ability to my family, friends, or others," (4.2). Overall results for this section show that extrinsic motivation is regarded as crucial by the respondents. 
(c) Task Value Beliefs

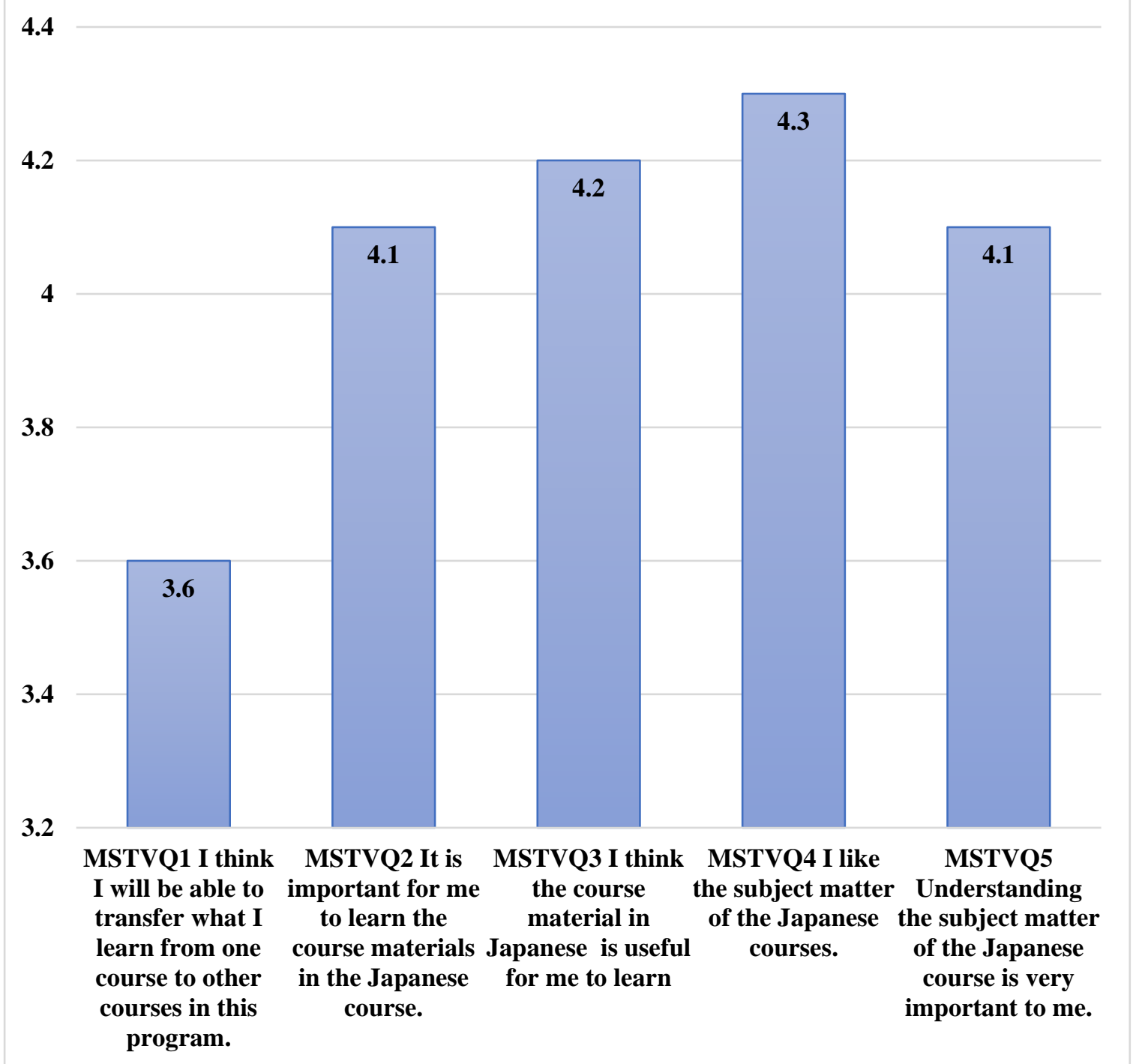

Figure 7-Mean for Task value Beliefs

Task value is defined as the incentive for engagement in academic activities and consists of four components, namely attainment value; intrinsic value; utility value and cost. (Wigfield \& Eccles, 1992). According to Zhang (2016), task value belief is a major predictor for academic achievement. Figure 7 presents the mean score for task value belief. The highest mean score (4.3) is for "I like the subject matter of the Japanese course", (4.2) "I think the course material in Japanese is useful for me to learn". Meanwhile, the mean score (4.1) is for "It is important for me to learn the course materials in the Japanese course", and "Understanding the subject matter of the Japanese course is very important to me" respectively. 
Findings for Actional Stage

This section presents data for answering research question- How is Actional stage done in foreign language learning? At the actional stage, learners use their (a) affective component, and (b) speaking and (c) listening strategies as fuel to stay motivated to learn the foreign language.

\section{(a) Affective Component}

3.75

3.7

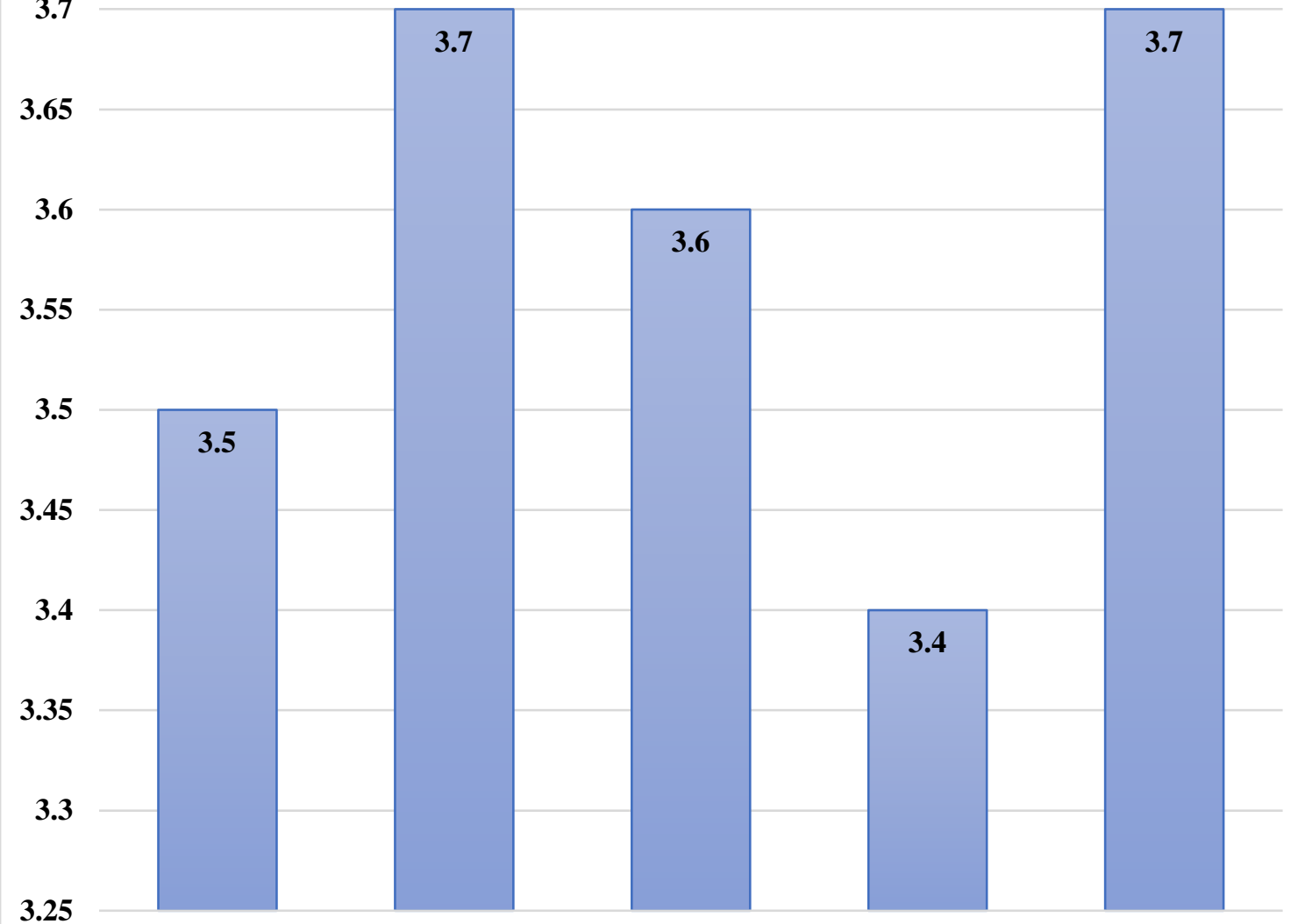

ACQ1 When I ACQ2 When I ACQ3 When I ACQ4 I have an ACQ5 I feel my take a test I think take a test, I think take tests I think uneasy, upset heart beating fast about how poorly about items on of the feeling when I I am doing other parts of the consequences of take an exam. when I take an compared with test I can't failing. other students. answer

Figure 8- Mean for Affective Component

Figure 8 shows the distribution by affective component. The mean score (3.7) is shared by items "When I take a test, I think about items on other parts of the test I can't answer" and ". I feel my heart beating fast when I take an exam." While the mean score (3.6) was for item "When I take tests I think of the consequences of failing" followed by mean scores (3.5) and (3.4) for items "When I take a test I think about how poorly I am doing compared with other students." and for "I have an uneasy, upset feeling when I take an exam." 
(b) Speaking Strategies

SPQ 10 If I cannot think during a conversation in Japanese, I use gestures.

SPQ9 I practice English with native speakers.

SPQ8 I practice speaking with my friends or my teachers.

SPQ7 Before I respond orally to questions, I write out the answers

SPG6 I put words into rules that I know in speaking.

SPQ5 I mix Malay words and foreign words if I do not know the foreign language words.

SPQ4 I try to translate the Bahasa Melayu sentences into the Japanese language sentences and produce them orally

SPQ3 I try to learn a new pattern by making a sentence orally

SPQ2 I speak a word or a sentence several times to remember it

SPQ1 I try to remember a new word in Japanese by pronouncing it

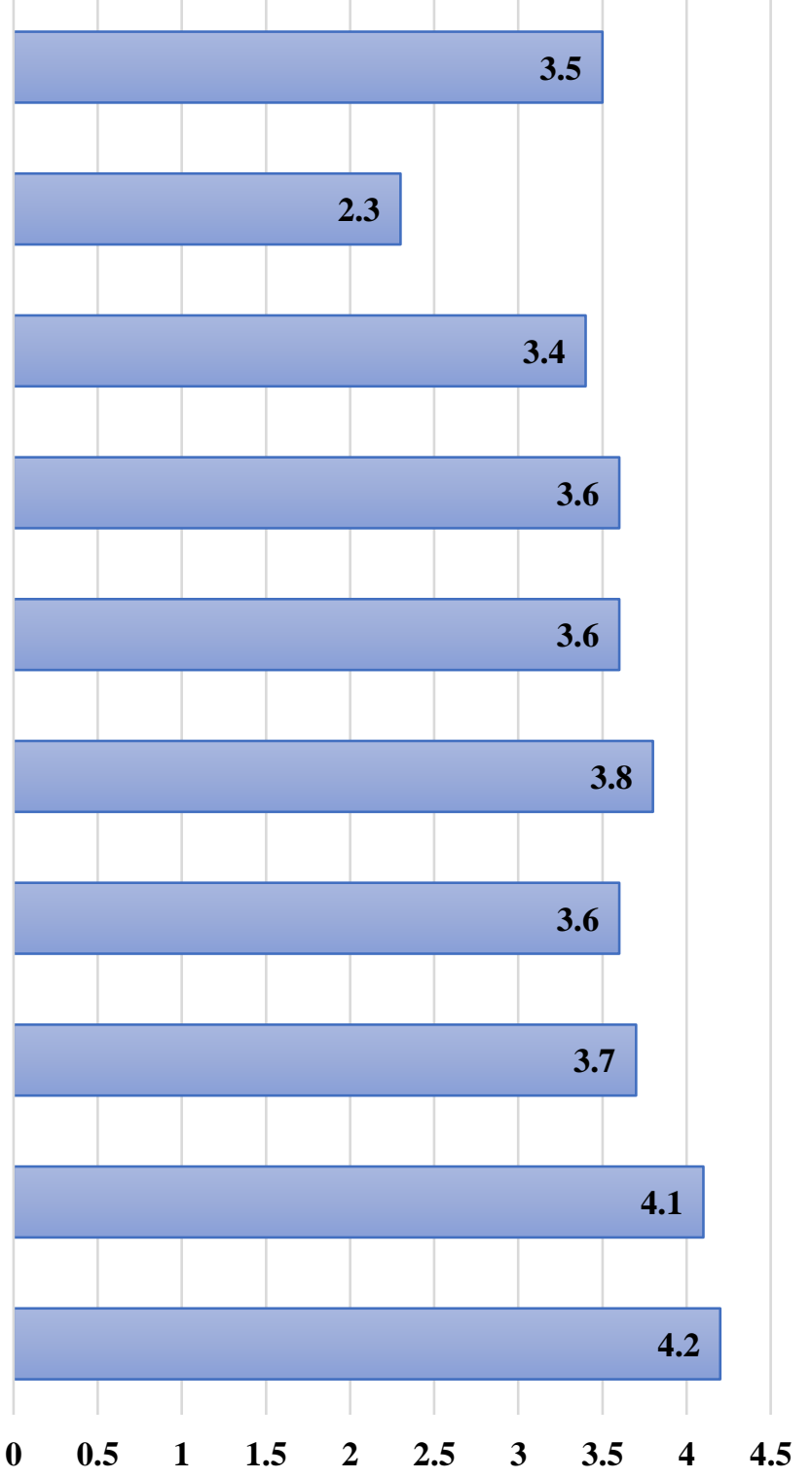

Figure 9 -Mean for Speaking Strategies

Figure 9 shows the distribution for language learning strategies in speaking. The highest was for "I try to remember a new word in Japanese by pronouncing it" with the mean score (4.2) followed by a mean score (3.8) and (3.7) for items "I mix Malay words and foreign words if I do not know the foreign language words." and "I try to learn a new pattern by making a sentence orally". The lowest mean score for this skill was (2.3) for the item "I practice English with native speakers." 
(c) Listening Strategies

SLQ10 In a group discussion, my listening is improved

SLQ9 Listening to what somebody is saying improves my listening skills

SLQ8 If I cannot understand what somebody is saying, I ask the person to slow down or say it again

SLQ7 After listening practice, I check and recheck my understanding

SLQ6 I try to guess by using a word (s) that is familiar to me

SLQ5 I concentrate on grammar rather than on the communication

SLQ4 I try to understand what somebody is saying by translating into Japanese language

SLQ3 I learn the language by listening to the songs in Japanese language

SLQ2 I learn the Japanese language by watching TV programs in that language

SLQ1 I try to guess when somebody is saying by using the grammatical rules

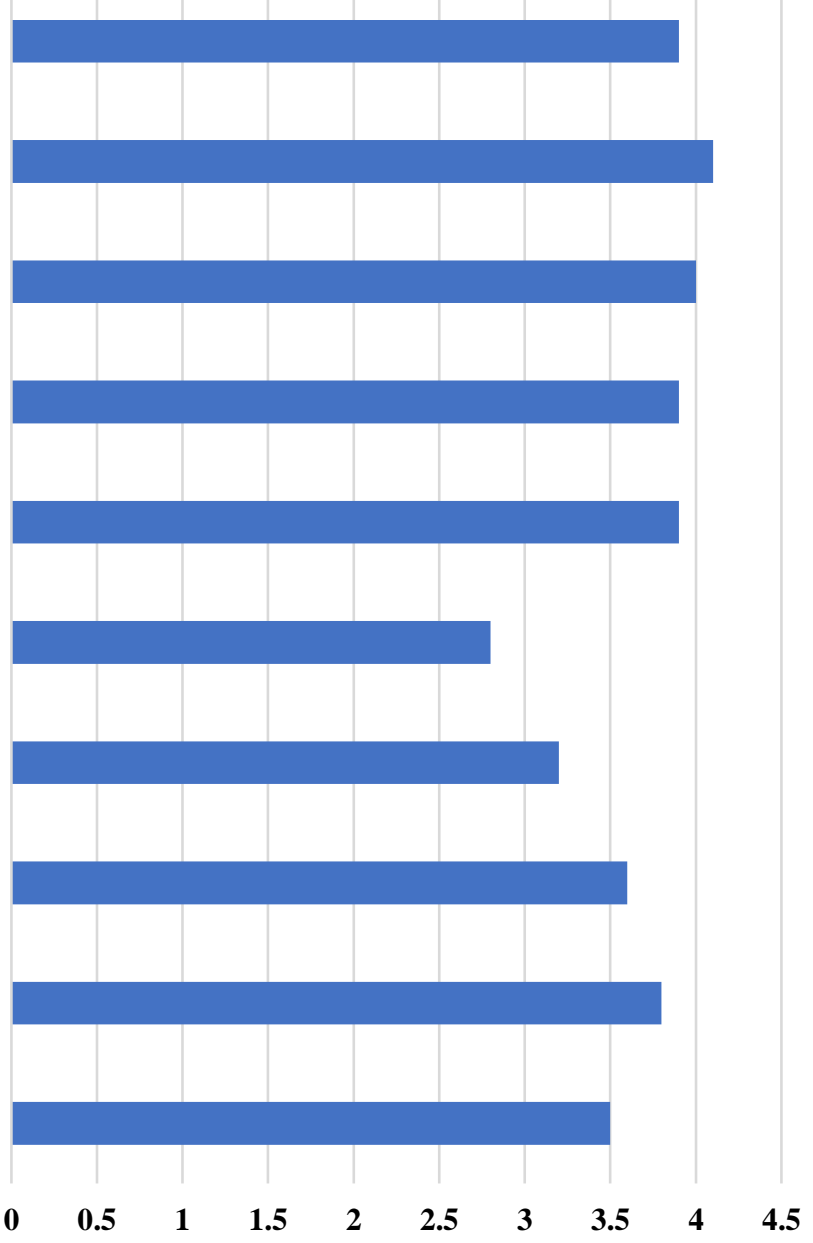

Figure 10-Mean for Listening Strategies

Figure 10 shows the distribution for language learning strategies in listening skills. The highest mean score was (4.1) for "Listening to what somebody is saying improves my listening skills" followed by "If I cannot understand what somebody is saying, I ask the person to slow down or say it again." with a mean score (4) and mean score (3.9) for the 3 items which were "I try to guess by using a word (s) that is familiar to me.", "After listening practice, I check and recheck my understanding" and "In a group discussion, my listening is improved". . While the lowest mean score was from listening for the item "I concentrate on grammar rather than on the communication" with a mean score (2.8).

Findings for Post Actional Stage

This section presents data to answer the research question-How is Post actional stage done in foreign language learning? At the post actional stage, learners depended on their (a) selfefficacy and (b) control beliefs for learning motivation. 


\section{(a) Students 'Perception Of Self-Efficacy}

$$
4
$$

3.9

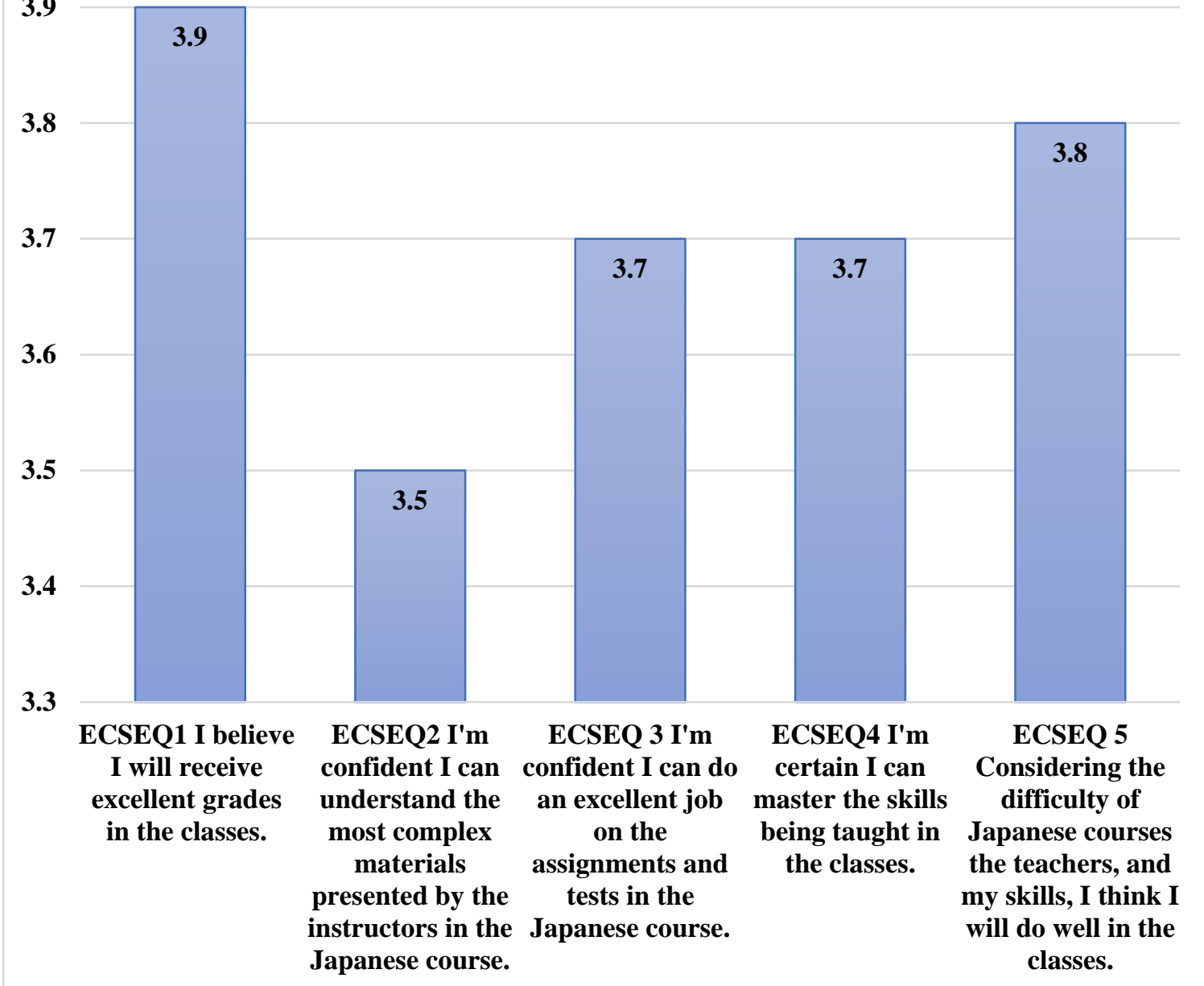

Figure 11- Mean for Self-Efficacy

Figure 11 shows the mean scores for students' perception of self-efficacy. The highest mean report is when students believe they will receive excellent grades (3.9). Interestingly, the second highest mean is when students consider the difficulty of Japanese courses, the teachers, and their skills, they think they will do well in the classes (3.8). The confidence of understanding the most complex materials in the Japanese course presented by the instructors is the lowest mean (3.5). 


\section{(b) Control Beliefs For Learning}

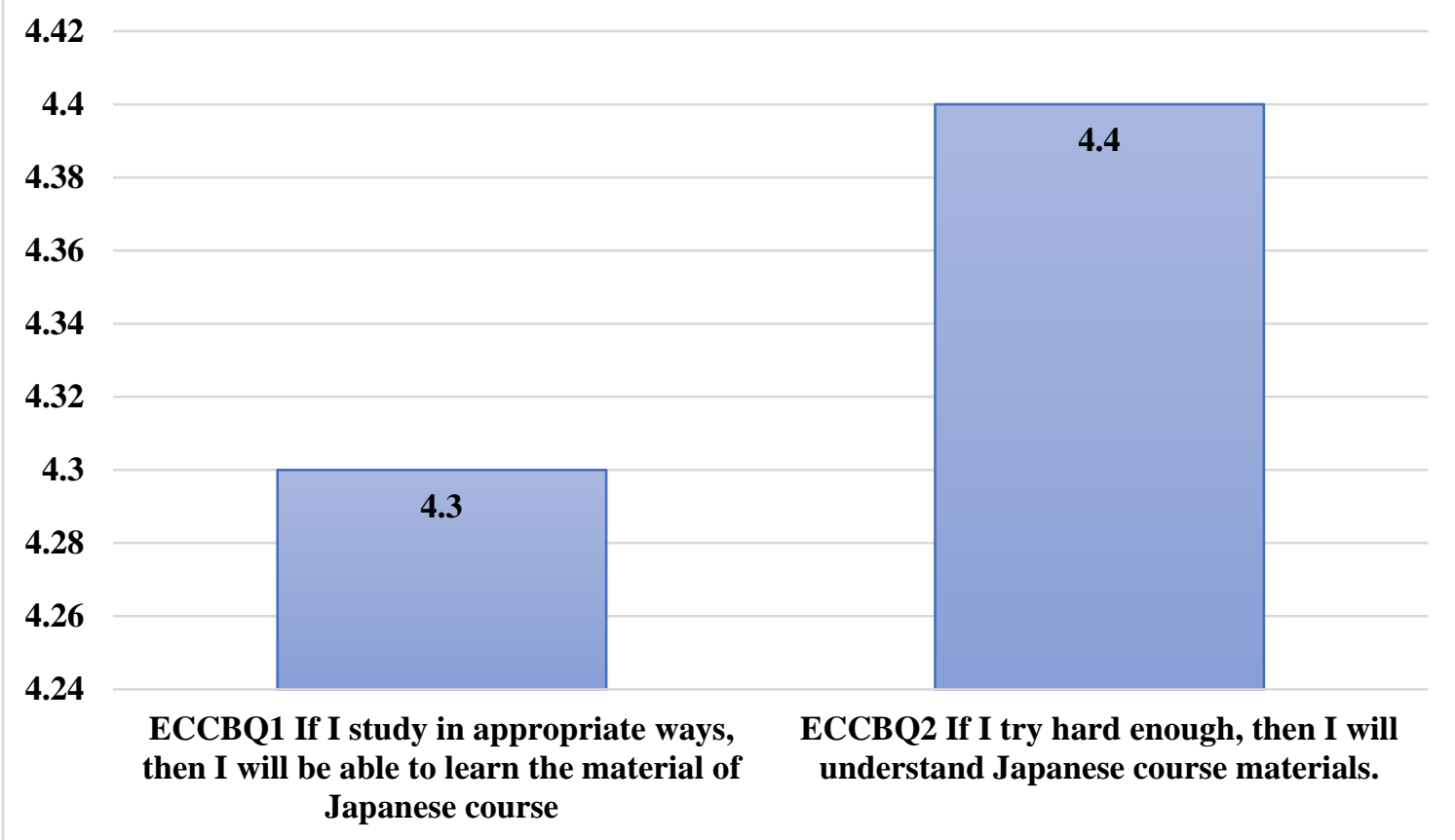

Figure 12-Mean for Control Beliefs

Figure 12 presents the finding for Control Beliefs for Learning regarding means scores. More students believe that if they try hard enough, they will understand Japanese course material (4.4) than the students who think they will be able to learn the material of the Japanese course, even if they study in appropriate ways (4.3).

\section{Conclusion}

\section{Findings and Discussion}

The motivation to learn a foreign language begins with the Pre-actional stage followed by the Actional stage and the last stage is Post-actional stage (Dörnyei \& Ottó, 1998 \& Setiyadi, 2016). This study has shown interesting findings on the three phases of motivation to learn the Japanese language.

Table 3: Total Mean for The Three Phases of Motivation In The Learning of Japanese

\begin{tabular}{|l|l|l|}
\hline \multicolumn{3}{|c|}{ Total Mean for The Three Phases of Motivation In The Learning of Japanese } \\
\hline 1 & Pre-Actional stage & 4.0 \\
\hline 2 & Actional Stage & 3.6 \\
\hline 3 & Post-Actional Stage & 3.9 \\
\hline
\end{tabular}

Table 3 indicates the total mean for the three phases of motivation in the Learning of Japanese. With reference to the findings in this study, the highest motivation in learning Japanese as a foreign language is during the pre-actional stage (mean=4.0). Learners' motivation decreases when the initial motivation has to be maintained and protected and 
involves executive motivation in the actional stage (mean=3.6). However, learners' motivation is to bounce back during the post-actional stage (mean=3.9).

\section{Preactional Stage In Foreign Language Learning}

At the Preactional stage, the learners are trying to understand the content of the Japanese course driven by their curiosity. Their curiosity-driven has intrinsically motivated them to learn (Dornyei, 1994). According to Gardner (1972), instrumental orientation refers to a person's practical motives for learning a language. Findings reveal that learners want to learn the Japanese language in order to have more chances to get a good job (Makhtiar Singh, 2021). Awang Boon et al. (2021) also found that learners in higher education are motivated to learn the Japanese language as it may be their ticket to be employed after graduation. Learners are also motivated to study the Japanese language because it is a requirement in the university. In order to get an external reward, getting a good grade became the main concern and had extrinsically motivated learners to engage (Dornyei, 1994). In addition, task value beliefs have become the motivation for engagement in Japanese language learning activities at the Preactional stage. It is also agreed by Wigfield \& Eccles, (1992) and Zhang (2016) that task value belief is a major predictor for academic achievement. Most of the learners believe that the course material in Japanese is useful and important for them to learn.

\section{Actional Stage In Foreign Language Learning}

According to Dornyei (1994), the actional stage is the stage during which the initial motivation has to be maintained and protected where executive motivation is involved. The actional stage is influenced by the learners' affective components. The learners then perform their ability to use the language via speaking and listening skills (Dörnyei \& Ottó, 1998 \& Setiyadi, 2016). Findings showed that learners' initial motivation has reversed when they reached the actional stage due to their stress about the tests or examinations. They are worried about their performance of the assessment due to lacking confidence. As reported by Rahmat (2020), anxiety caused by lacking confidence while having tests or examinations may demotivate learners. Hence, when learners start to get involved in foreign language learning such as speaking and listening skills, they are demotivated by the task or tests which are challenging. This finding is in line with a study done by Rethinasamy (2021) where most of the learners believe that listening and speaking skills are more difficult to obtain compared to reading and writing skills and most students are unsure about their abilities to communicate in Japanese. Rethinasamy (2021) also reported that most of the students lack the confidence to speak in Japanese. However, in order to improve their Japanese language learning in the actional stage, learners showed their effort to overcome their learning problems. For instance, learners try to remember new words and new sentences by pronouncing them repeatedly. They speak a word or a sentence several times to remember it. Most of the learners also try to improve their listening skills by listening to TV programs, songs or guessing the meaning of what somebody is saying. Hoi (2021) agrees that watching movies helps Japanese learners expand their vocabulary, and improve pronunciation and listening skills. Learners try to maintain and protect their initial motivation in this actional stage (Dornyei, 1994).

\section{Post Actional Stage In Foreign Language Learning}

Post actional stage is the last stage where learners are influenced by the learners' perception of self-efficacy and also their control beliefs (Dörnyei \& Ottó, 1998 \& Setiyadi, 
2016). It indicates some kind of evaluation of the learning process (Dornyei, 1994). Findings show that learners are confident they will perform an excellent job on their assessments or assignments. From learners' past Japanese learning experiences, they strongly believe that they will understand Japanese course material if they try hard enough. The high self-efficacy in the post-actional stage helped learners make progress as planned in learning even if the learning may sometimes be tough.

\section{Pedagogical Implications}

Motivation is a significant factor that determines success in learning a foreign language (Amjoshoa \& Sadighi, 2015). This study provides visions for the Japanese language instructors who are teaching in higher institutions to understand the three phases of motivation in learning Japanese as a foreign language. Thus, it is necessary for instructors, resource persons and universities as well as policymakers to understand the motivation of learning which is dynamically changing in time. This study reveals that instructors have a role to play to keep students motivated throughout the process of Japanese language learning. Students' learning motivation at different stages ought to be taken into consideration to ensure effective teaching and learning activities achieve the goals in the different phases of learning.

\section{Suggestions for Future Research}

This study aims to improve motivational strategies for the purpose of Japanese language teaching and learning. As mentioned by Dörnyei \& Ottó (1998), the action sequence dimension that presents the motivational process sequentially is said to be incomplete if not accompanied by an additional dimension of motivation in regards to influences that would power the actional sequence. Further research can be done on these external motivational influences that study cognitive, affective, situational factors or conditions that will substantiate and complement the research on the actional sequence.

\section{References}

Anjomshoa, L., \& Sadighi, F. (2015) The Importance of Motivation in Second Language Acquisition. International Journal on Studies in English Language and Literature (IJSELL) Vol. 3, Issue 2, February 2015, pp 126_137 ISSN 23470-3134 (online). Available at: https://www.arcjournals.org

Boon, A. M. H., Abdullah. N. A. T., Rahmat, N. H., Ahmad, N., Sharif, S., \& Choong, P. Y. (2021)Balancing Negative and Positive Factors in Foreign Language Learning. International Journal of Asian Social Science Vol. 11, No. 8, pp 376-387. ISSN(e) 2224-4441. Available at: https://10.18488/journal.1.2021.118376.387

Bidin, S. H., Abdullah, H. J., Zan, N. S., Kadir, Z. A., Abdullah, R. A. (2021). Attitudes, Motivation and Gender Factors affecting Level 1 Japanese Language Learning at Universiti Tun Hussein Onn Malaysia. Journal of Advanced Research in Social and Behavioural Sciences 16, Issue 1 (2019) 105-115. ISSN: 2462-1951. Available at www.akademiabaru.com/arsbs.html

Chong, M. Y. C., Renandya, W. A., \& Ng, Q. R. (2019). Demotivation in L2 classrooms: Teacher and learner factors. LEARN Journal: Language Education and Acquisition Research Network, 12(2), 64-75. https://so04.tcithaijo.org/index.php/LEARN/article/view/205071/142770

De Burgh-Hirabe, R. (2019). Motivation to learn Japanese as a foreign language in an 
English-speaking country: An exploratory case study in New Zealand. System, 80, 95106. https://doi.org/10.1016/j.system.2018.11.001

Djafri, F., \& Wimbarti, S. (2018). Measuring Foreign Language Anxiety Among Learners of Different Foreign Languages: In Relation to Motivation and Perception of Teacher's Behaviors. Asian-Pacific Journal of Second and Foreign Language Education. Retrieve from https://sfleducation.springeropen.com/articles/10.1186/s40862-018-0058-y

Dörnyei, Z., \& Ottó, I. (1998). Motivation in action: A process model of motivation. Working Papers in Applied Linguistics, 4, 43-69. Retrieved from https://nottinghamrepository.worktribe.com/preview/1024198/Motivation_in_action.pdf

Gardner, R. C., \& Lambert, W. (1972). Attitudes and Motivation in Second Language Learning. Rowley, Mass. : Newbury House Publishers.

Hoi, H. T. (2021). Some Methods of Learning Intermediate Japanese with Movies. Revista Geintec Vol. 11 No.3 (2021). ISSN: 2237-0722. Available at www.revistaintec.net

Jahedizadeh, S., Ghanizadeh, A., Ghonsooly, B. (2016). The role of EFL learners' demotivation, perceptions of classroom activities, and mastery goal in predicting their language achievement and burnout. Asian-Pacific Journal of Second and Foreign Language Education (2016) 1:16. Available at:

https://sfleducation.springeropen.com/track/pdf/10.1186/s40862-016-0021-8.pdf

Kuraesin, U. (2021). Factors That Cause Difficulty Learning Japanese. Review Of International Geographical Education. Retrieved from https://rigeo.org/submit-amenuscript/index.php/submission/article/view/1616/1259

Mardani, D. (2019). Learning Japanese Language Based on 2013 Curriculum at Elementary

Schools in Bali. Advances in Social Science, Education and Humanities Research, volume 394 3rd International Conference on Innovative Research Across Disciplines (ICIRAD 2019). Retrieved from

https://www.atlantis-press.com/proceedings/icirad-19/125932495

Mese, E. (2021). Factors influencing EFL students' motivation in online learning: A qualitative case study. Journal of Educational Technology and Online Learning. Volume 4, Issue 1. Retrieved from

https://dergipark.org.tr/en/pub/jetol/issue/60134/817680

Osumi, A. (2019) Exploring Motivation For Learning Japanese As A Foreign Language. (Thesis PhD yang tidak diterbitkan). Purdue University.

Pintrich, P. R., \& De Groot E. V. (1990). Motivational and self-regulated learning

Components of classroom academic performance. Journal of Educational

Psychology, 82(1), 33-40.

Rahmat, N. H. (2020). Investigating the cycle of fear in foreign language learning. European Journal of Foreign Language Teaching, 5(1), 117-127. Available at: https://doi.org/10.46827/ejfl.v5i1.3245

Rahmat, N. H. (2021). Social Learning During Online Learning? The Case for Japanese Language. International Journal . Vol. 11.No.3. Retrieved from https://doi.org/10.18488/journal.1.2021.113.168.176

Ramírez, N. O. (2014) The Influence of Motivation in Foreign Language Learning Process. Fórum De Recerca, No 19/2014. Pp 695-707. ISSN 1139-5486. Available at http://dx.doi.org/10.6035/ForumRecerca.2014.19.44

Rethinasamy, S., Paee, R., \& Ramanaic, J. (2021). Malaysian Undergraduates' Beliefs and Motivation for Learning Japanese as a Foreign Language. Turkish Online Journal of Qualitative Inquiry, 12(6). 
https://www.tojqi.net/index.php/journal/article/view/1394

Setiyadi, A. B. (2016) Language Learning Strategy Questionnaire (LLSQ) A Measurement to identify Students' Learning Strategies and Prepare the Success of Learning English in the Indonesian Context (Empirical Evidence). Indonesia: Graha IImu. Retrieved from http://repository.Ippm.unila.ac.id/8847/2/isi\%20buku.pdf

The Japan Foundation. (2015). Survey on Japanese Language Education Abroad. Tokyo, Japan. Retrieved from https://www.jpf.go.jp/e/project/japanese/survey/result/survey15.html

The Japan Foundation. (2018). Survey on Japanese Language Education Abroad. Tokyo, Japan. Retrieved from https://www.jpf.go.jp/e/project/japanese/survey/result/survey18.html

The Japan Foundation 2019-2020 Annual Report. Retrieved from: https://www.jpf.go.jp/e/about/result/ar/2019/pdf/dl/ar2019e.pdf

Wigfield, A., \& Eccles, J. (1992). The Development of Achievement Task Values: A Theoretical Analysis. Developmental Review, 12, 265-310. http://dx.doi.org/10.1016/0273-2297(92)90011-P

Zhang, Y., Hawk, S. T., Zhang, X., \& Zhao, H. (2016). Chinese Preservice Teachers' Professional Identity Links with Education Program Performance: The Roles of Task Value Belief and Learning Motivations. Frontiers in psychology, 7, 573. https://doi.org/10.3389/fpsyg.2016.00573 